\title{
7. Advertising's Self-Reference: From Early Cinema to the Super Bowl
}

\author{
Yvonne Zimmermann
}

\begin{abstract}
This chapter takes up the notion of self-reference and self-reflexivity so present in cinema, media and literature studies, if only to redefine it. Self-reference is no longer understood as a textual feature of revelation that produces knowledge about media, but as a particular mode of address: when looking at self-reference from the perspective of screen advertising and screen ads, it becomes evident that rather than displaying the medium itself, self-reference acts against reactance in that it exhibits the assumed media knowledge of the viewers and celebrates media expertise. Thus, the chapter contributes to discussions about the many notions and layers of self-reference and self-reflexivity in cinema and media studies.
\end{abstract}

Keywords: self-reference, self-reflexivity, advertising, media expertise, reactance

Self-reference is a multidisciplinary object of research, as Steven J. Bartlett and Peter Suber's comprehensive survey of themes and studies in more than 20 fields of research illustrates. ${ }^{1}$ While literature on self-reference in art and media is abundant, self-reference in advertising has been the subject of only a rather small number of studies, and these studies are mostly dedicated to print advertising. ${ }^{2}$ In a similar vein, while cinema has lent itself to plentiful explorations of its self-referential dimensions, only a few works, mostly

1 Steven J. Bartlett and Peter Suber, eds., Self-Reference: Reflections on Reflexivity (Dordrecht: Nijhoff, 1987).

2 See, for instance, the three contributions on self-referential advertising in Winfried Nöth and Nina Bishara, eds., Self-Reference in the Media (Berlin and New York: De Gruyter, 2008); Winfried Nöth, Nina Bishara, and Britta Neitzel, 'Selbstreferenz in der Werbung', in Mediale

Florin, B., P. Vonderau, Y. Zimmermann, Advertising and the Transformation of Screen Cultures. Amsterdam: Amsterdam University Press, 2021 DOI 10.5117/9789462989153_CHO7 
from the field of communication studies, deal in a pronounced way with self-reference in moving image advertising. More often than not, such research privileges references of moving image advertising for films over other types of self-reference and shows particular interest in retracing quotations, allusions, and other intertextual relations between commercials and cinema. ${ }^{3}$ This is certainly a rich field to investigate, given the seemingly ever-increasing circulation of personnel, motives, narratives, generic codes, and stylistic features between movies and commercials - all markers of the entangled intertextual relationship between advertising culture and entertainment industry. Other types of self-reference in moving images, however, have been neglected, so that the phenomenon in its entirety still remains to be explored.

Moreover, self-reference in advertising has largely been studied as an isolated topic and has rarely been considered in a larger context of selfreference in media. My attempt in the following is to broaden the perspective and include forms of self-reference in literature and cinema in the discussion of self-reference in moving image advertising. I do this for two reasons. First, this broader approach promises to provide a better understanding of the particularities of self-reference in moving image advertising. Second, it allows for the reconsideration of the concepts of self-reference in literature and cinema studies in light of self-reference in moving image advertising. It should be clear from the start that self-reference in any kind of advertising is a sales strategy. But instead of being satisfied with criticizing advertising for being and doing advertising, as critical studies tend to, I think it is worth taking a closer look at how self-reference is manifested in moving image advertising and how it interacts with viewers. I will argue that rather than being a textual feature, self-reference in moving image advertising is a particular mode of address - one that acknowledges, exhibits, and celebrates media expertise that advertisers assume audiences have. In that sense, selfreference not only adds another mode of address, the celebratory mode, to the list of self-referential modes of address in art and popular visual culture.

Selbstreferenz: Grundlagen und Fallstudien zu Werbung, Computerspiel und den Comics (Cologne: Halem, 2008), 57-118.

3 See, for example, Gloria Withalm, 'Commercial Intertextuality', in Logica, dialogica, ideologica. I segni tra funzionalità ed eccedenza, ed. Patrizia Calefato (Milan: Mimesis, 2003), 425-435; Gloria Withalm, 'Recycling Dorothy, Dinosaurs, and Dead Actors: Digi-Textuality in the TV-Commercials of the 1990s', Semiotische Berichte 27, no 1 (2003): 297-315; Gloria Withalm, 'Commericalization of Filmic Self-referentiality', Semiotica 148, no. 1-4 (2004): 337-360; Ursula von Keitz, 'Adaption und Funktionalisierung von Spielfilmcodes im neueren Werbefilm', Spiel 11, no. 1 (1992): 165-189. 
It also tells us something about what advertisers - and media producers in general - think they know about what viewers know about media.

As far as the term self-reference is concerned, I share Winfried Nöth's semiotic understanding of a self-referential sign as 'any sign that refers to itself or to aspects of itself'. ${ }^{4}$ In literature, cinema, and media studies, as well as in cultural studies, self-reference in this broad sense is sometimes used as synonym for, but sometimes distinguished from, concepts such as reflexivity, self-reflexivity, self-representation, or autoreferentiality. ${ }^{5}$ In his 1985 book Reflexivity in Film and Literature, Robert Stam uses the term reflexivity to describe 'the process by which texts, both literary and filmic, foreground their own production, their authorship, their intertextual influences, their reception, or their enunciation', whereas self-referentiality for Stam designates the ways in which texts can refer or point to themselves. ${ }^{6}$ Robert Goldman and Stephen Papson, in Sign Wars: The Cluttered Landscape of Advertising (1996), which to my knowledge is the only nearly book-length study of self-reference in moving image advertising, define media self-referentiality and intertextuality as the process by which 'ads either refer to other ads or are about the subject of advertising itself as a method of positioning the commodity brand name'. For Michael Dunne, self-referentiality is advertisement 'of a communicator's presence'. ${ }^{8} \mathrm{His}$ 1992 study Metapop: Self-referentiality in Contemporary American Popular Culture draws on examples of self-referentiality from television, film, rock and country music, music videos, and comic strips. It has no particular focus on advertising, but includes a few examples of self-referential ads.

Within the semiotic framework of self-reference in the media outlined by Nöth, the forms of self-reference this essay focusses on are enunciative (or communicative) self-reference, metatextual self-reference, and intertextual self-reference. Enunciative or communicative self-reference 'involves the communicative situation and describes reference of the speaker, writer, composer, or producer of the sign but also the role of the audience or spectators'. Metatextual self-references, on the other hand, are 'comments on the

4 Winfried Nöth, 'Self-Reference in the Media: The Semiotic Framework', in Self-Reference in the Media, 8.

5 For more details, see ibid.

6 Robert Stam, Reflexivity in Film and Literature. From Don Quixote to Jean-Luc Godard (New York: Columbia University Press, 1992 [1985]), xiii resp. xiv.

7 Robert Goldman and Stephen Papson, Sign Wars: The Cluttered Landscape of Advertising (New York and London: The Guilford Press, 1996), 15.

8 Michael Dunne, Metapop: Self-referentiality in Contemporary American Popular Culture (Jackson and London: University Press of Mississippi, 2010 [1992]), 4. 
text, its narrative form, its content and its structure, its plot, previous or subsequent chapters, its beginning and its end'. ${ }^{9}$ According to this description, metatextual reference is a type of self-reference that is elsewhere often addressed as self-reflection, self-representation, or self-reflexivity. The sources of intertextual self-reference in Nöth's system of definitions are 'quotations, allusions, adaptations, influences, borrowings from texts, films, or any other medium'. ${ }^{10}$ Intertextuality typically manifests itself, to quote Gérard Genette, 'as the actual presence of one text within another text'. ${ }^{11}$ If in the following the term self-reference is used, it is to refer to these particular communicative, metatextual, and intertextual forms of self-reference, which include forms that are often addressed as reflexivity or self-referentiality. ${ }^{12}$

\section{Self-Reference in Art, Literature, and Cinema}

Studies on self-reference in art, literature, and cinema usually focus on a tradition of reflexivity that interrogates conventions 'which break with art as enchantment and point to their own factitiousness as textual constructs' ${ }^{13}$ Reflexivity, according to Robert Stam, 'subverts the assumption that art can be a transparent medium of communication, a window on the world, a mirror promenading down a highway'. ${ }^{14}$ Reflexivity demystifies fictions and our naïve faith in fiction, and, according to Stam, makes this demystification a source for new fiction. ${ }^{15}$

In documentary studies, reflexivity is also regarded as a form that draws attention to the process of selecting and reconstructing events to convey meaning. As Jeanne Allen puts it in her essay 'Self-reflexivity in

9 Nöth, 'Self-Reference in the Media', 15, 18.

10 Ibid., 19.

11 Gérard Genette, Palimpsets. Literature in the Second Degree (Lincoln: University of Nebraska Press 1997 [1982]), 1.

12 I do not distinguish, as some authors do, between self-reference as allegorical or metaphorical use of self and reflexivity as conscious awareness, i.e., being conscious of self-consciousness. Jay Ruby, for example, holds that one can be reflective without being reflexive (Jay Ruby, 'The Image Mirrored: Reflexivity and the Documentary Film', in New Challenges for Documentary, ed. Alan Rosenthal [Berkeley: University of California Press, 1988], 66). This distinction sounds convincing in theory, but when it comes to specific examples, it is often hard to tell whether they are 'truly' reflexive or 'only' reflective.

13 Stam, Reflexivity in Film and Literature, xi.

14 Ibid.

15 Ibid. 
Documentary': 'Self-reflexivity becomes then a reaction against or a way of countering the traditional mode of the documentary which emphasizes verisimilitude'. ${ }^{16}$ Or, as Jay Ruby also in regard to the documentary claims: 'Reflexivity offers us a means whereby we can instruct our audiences to understand the process of producing statements about the world'. ${ }^{17}$

In these studies, self-reference is addressed as a signature of both modern art and postmodern culture and, in line with Bertolt Brecht, is understood - and celebrated - as a critical method. For Brecht, drawing attention to the constructed nature of a text triggers 'alienation effects' that serve as a means to open those texts to audience dialogue and criticism. With Fernando Andacht, the discourses on self-reference in art, media, and cinema studies can be summed up as follows:

Reflexivity has been hailed as a noble component of high culture and equally as a valuable method of high theory. In the realm of culture, reflexivity serves to make explicit and to explore artistically the selfconsciousness that a [sic] creators put into their works of representation. ${ }^{18}$

Self-reference, so we can conclude, has been understood as an analytical tool for critical thinking about media and appraised as a moral, political, and epistemological virtue.

But, as Stam underlines, '[r]eflexivity comes with no pro-attached political valuence. ${ }^{19}$ In other words, self-reference is not perceived as a virtue per se. As a matter of fact, Stam distinguishes between two kinds of reflexivity, between 'authentic' and 'debased' reflexivity. Taking the example of commercial television, Stam holds that this kind of reflexivity is 'ambiguous' and often of a 'debased' kind because commercial television does not trigger any alienation effects. Rather, as Stam criticizes, "[t]he commercial interruptions that place programs on hold [...] are not pauses for reflection but breaks for manipulation, intended not to make us think but to make us feel and buy'. ${ }^{20}$ Going on from television to moving image advertising, Stam asserts that

[t]he self-referentiality of commercials that parody themselves or other commercials $[. .$.$] are calculated to mystify rather than disenchant. The$

16 Jeanne Allen, 'Self-Reflexivity in Documentary', Ciné-Tracts 1, no. 2 (1977): 37.

17 Ruby, 'The Image Mirrored', 75 .

18 Fernando Andacht, 'On the Use of Self-disclosure as a Mode of Audiovisual Reflexivity', in Self-Reference in the Media, 177 .

19 Stam, Reflexivity in Film and Literature, xvi.

20 Ibid., 16. 
self-referential humour signals to the spectator that the commercial is not to be taken seriously, and this relaxed state of expectation renders the viewer more permeable to its message. The self-referentiality, far from demystifying the product or exposing hidden codes, conceals the deadly seriousness of the commercial - the fact that it is after the spectator's money. ${ }^{21}$

For Stam, self-reference in moving image advertising is not an instrument of demystification and revelation; on the contrary, it is a perfidious strategy of lulling the spectators' critical senses and of concealing the commercial's true agenda. Whereas 'authentic' reflexivity in Stam's view elicits an actively thinking spectator, 'debased' reflexivity as found on television and in moving image advertising elicits a passive consumer of entertainment whose viewing habits as well as buying habits television and moving image advertising aim to transform. ${ }^{22}$

In a similar vein, neo-Marxists Robert Goldman and Stephen Papson assert that reflexivity as a critical method has 'been absorbed by advertising and used against the intention of critics'. ${ }^{23}$ In advertising, the authors claim, reflexivity has been perverted into a strategy to 'reroute viewer criticism' and 'to create an emphatic relationship with the audience by foregrounding the constructed nature of the text'. ${ }^{24}$ Advertising practices are seen to turn self-reflexive awareness of advertising codes into an object of consumption. Hence, in Goldman and Papson's eyes, reflexivity in advertising is commoditized reflexivity. Self-referential moving image advertising is dispraised for perverting the 'enlightening' function of self-reference in modernism and for turning it into a cynical selling strategy.

This broadside on self-reference in advertising dates back to at least the 1960s. Renowned film critic Pauline Kael, in her 1965 article 'Spoofing and Schtik', reads the fact that 'advertising kids advertising, TV commercials kid TV commercials, movies kid movies' as a symptom of 'a commercialized society that nobody believes in'. ${ }^{25}$ This disbelief poses a problem to advertising. Therefore, TV commercials are trying to outwit disbelief by including it in the sell. But unlike satire, spoofing - Kael does not use the term self-reference or reflexivity - has no serious goals: 'It's just a technique

Ibid., 16.

Ibid., $16 f$.

Goldman and Papson, Sign Wars, 74.

Ibid.

Pauline Kael, 'Spoofing and Schtik', Atlantic Monthly (December 1965): 85 . 
of ingratiation: the spoof apologizes for its existence, assures us that it is harmless, that it isn't aiming for beauty or expressiveness or meaning or even relevance. ${ }^{26}$ Self-reference in Kael's view is a new kind of flattery of the customer, a new selling strategy based on ingratiation. ${ }^{27}$

To summarize, research into self-reference asserts that there are different types of self-reference, and that these different types are appraised differently. On the one hand, there is 'authentic', critical, and therefore 'good' self-reference in modernist art, novels, and films such as Dziga Vertov's Man with a Movie Camera (1929); on the other hand, there is 'debased', uncritical, entertaining, perverted, and therefore 'bad' self-reference in popular culture, television, and commercials.

Ultimately, critical studies criticize self-reference for being a selling strategy in advertising. And yes, it is. But then, what else could it be? It is advertising after all. However, we can be more precise about the nature of this strategy. Self-reference in moving image advertising is a strategy to act against reactance. The theory of psychological reactance, which was introduced by Jack W. Brehm in the mid 196os, explains negative motivational reactions to influence attempts that are perceived to threaten behavioural freedoms ${ }^{28}$ From this perspective, self-reference in advertising can be understood as a strategy to overcome viewers' negative attitude towards commercials. How commercials make use of self-reference in their attempt to eschew audience reactance will be discussed in detail later on. First, let us look at an alternative approach to self-reference in advertising.

\section{Self-Reference in Advertising According to Systems Theory}

While critical studies in concert with media and cinema studies blame self-reference in advertising as a cynical form that does not reveal, but instead conceals and curries favour, systems theory considers self-reference

26 Ibid.

27 A somewhat similar result is found in Jane Feuer's analysis of self-referential Hollywood musicals. Feuer observes that musicals may use the same 'Brechtian' techniques as Jean-Luc Godard did in his films, but the effect is different. In musicals, self-reference in the form of direct address to the spectator, backstage musicals, and behind-the-scenes footage does not trigger alienation, but is a pattern of demystification and remystification: 'Demystification is always followed by a new mystification, the seamless final show or placing back on her pedestal of a disgraced performer.' Jane Feuer, The Hollywood Musical (Bloomington and Indianapolis: Indiana University Press, 1993 [1982]), 44.

28 Jack W. Brehm, A Theory of Psychological Reactance (New York: Academic Press, 1966). 
in advertising to be a privileged site of knowledge about advertising. It is therefore worth taking a closer look at what exactly can be learned from self-reference in advertising about advertising, according to systems theory. Indebted to Niklas Luhmann's theory of social systems, German communication scholar Siegfried J. Schmidt, in his article 'Modes of Self-Reference in Advertising', conceptualizes advertising in terms of a social system that represents a subsystem of the economic system. ${ }^{29}$ As is characteristic of all systems, according to Luhmann's theory, advertising follows its own system-specific logic. The specific logic of the advertising system consists of a particular form of communication, which Schmidt along with Guido Zurstiege ${ }^{30}$ - terms a 'macro-form of communication'. Within this theoretical framework, advertising is described as one of four 'macro-forms of communications', the others being journalism, literature and art, and public relations. Each of these macro forms of communication possesses different modes of reference to 'reality' and of self-reference. Schmidt identifies five modes of self-reference, holding that - and this is Schmidt's general hypothesis - 'only owing to self-referential maneuvers of or in the advertising system we as the addressees of media supply are able to observe the advertising system at all' ${ }^{31}$ In other words, for Schmidt, the only way we can observe - and learn about - the advertising system is through self-reference in advertising.

The first among the five modes of self-reference in advertising that Schmidt identifies is intertextuality, which includes, as mentioned above, citations, repetitions, recursions, or other kinds of reference to signs, texts, or other media. Advertising referring to the advertising system is mentioned as the second type of self-reference in advertising and is described as advertisers advertising for advertising, a practice that, according to Schmidt, makes advertising a topic and demands attention for itself, mostly in ironic and humorous ways. The third mode consists of advertising observing its own practices by means of advertising research carried out by advertising agencies themselves. The last two types of self-reference in advertising that, according to Schmidt, allow observation of the advertising system are self-descriptive statements by advertising agencies (concerning their own visions, missions, and philosophies) and manuals and how-to literature about best practices

29 Siegfried J. Schmidt, 'Modes of Self-Reference in Advertsing', in Self-Reference in the Media, 47-6o.

30 See, for instance, Guido Zurstiege, Zwischen Kritik und Faszination: Was wir beobachten, wenn wir die Werbung beobachten, wie sie die Gesellschaft beobachtet (Cologne: Halem, 2005).

31 Schmidt, 'Modes of Self-Reference in Advertising', $5^{0 .}$ 
in advertising written by advertisers. In systems theory, so we can conclude, self-reference is first of all considered an instrument of observation and a, if not the, epistemic key to an understanding of advertising.

\section{Self-Reference in Moving Image Advertising}

While I do share the assumption of advertising studies indebted to systems theory that self-reference in advertising has epistemological value, it needs to be examined what exactly we can learn from self-referential moving image advertisements about advertising that we don't already know. But before going into this question, we should take a closer look at the prevalent forms of self-reference in moving image advertising and at the methods commercials use to act against audience reactance. This is illustrated by a few pertinent examples. To begin with, it can be acknowledged that moving image advertisements are self-referential on all possible levels: they address the producer, the process, and the product of advertising; they refer to modes of text production and text reception; they foreground the materiality, temporality and mediality of moving image advertising as well as its historicity; and they lay open rhetorical and economic processes of advertising. Thereby, they make use of the entire arsenal of reflexive devices that Christian Metz in Impersonal Enunciation, or the Place of Film (1991) lists as follows: direct visual address to the camera, direct verbal address, reflexive intertitles, the frame-within-the-frame, the film-within-the-film, subjective imagery, and the display of the apparatus. ${ }^{32}$

The gamut of self-reference in moving image advertising could be studied by drawing on particular advertising campaigns such as the Bo Knows series of television commercials, which ran in 1989 and 1990, for Nike cross-training shoes with baseball and American football player Bo Jackson. The series heavily relies on metacommunication, intertextuality, and self-reflexive awareness. In 'Air. By Bo Jackson' (1991),33 for example, Jackson interrupts the production of an over-the-top musical number in which he serves as the lead singer, stating: "This is ridiculous. I am an athlete, not an actor. Let me out of this thing.' He walks off the set and steps out of a television screen right

32 Christian Metz, L'Enonciation impersonnelle, ou le site du film (Paris: Klinksieck, 1991) / Impersonal Enunciation, or the Place of Film, trans. Cormac Deane (New York: Columbia University Press, 2016 [1991]).

33 'Air By Bo Jackson Nike Television Commercial 1991 - Air Trainer Max 91', https://www. youtube.com/watch?v=dgp4gXEIh4Y (last accessed 6 April 2021). 
into the living room of a dazzled family gathered around the TV set, takes his Nike shoes with him, and goes straight to the gym for exercise. When the jingle of the musical is heard in the gym, Jackson yells at a screen-filling wall covered with the Nike Air logo that he does not have time for this. Cut to George Forman in the same musical set seen before, stating with a big smile: 'But I do.' The possibly conflicting tasks of a spokesperson and a sportsman and the possibly conflicting interests between a corporation and its spokesman are openly addressed in this commercial.

The same issue surfaces in another Nike campaign with Michael Jordan and Spike Lee playing Mars Blackmon, the same character (a big fan of the New York Knicks and Air Jordan shoes) Lee played in his 1986 comedy She's Gotta Have It. ${ }^{34}$ Mars wants to know what makes Jordan the best player in the universe and insists that it has to be the shoes. When Jordan repeatedly denies that it is the shoes, an intertitle appears on the screen that reads: 'Mr. Jordan's opinions do not necessarily reflect those of Nike, Inc.. This corporate comment draws attention to the fact that spokespersons and corporations may have different opinions on products and certainly do have different agendas. In both Nike campaigns, the audience is repeatedly directly addressed both visually and verbally. An early 1990 os Bo Jackson commercial with Denis Leary from the Bo Knows series ${ }^{35}$ refers to Jackson's hip injury and shows him working out, commented on by Leary who, all of a sudden, looks straight into the camera and aggressively shouts: 'And what are you and your good hip doing right now? Watching commercials!!!' The ad reproaches the audience for doing what the corporation wants the audience to do: watch commercials. Leary knocks at the screen and threatens to come in and bring Bo and his big bad hip' with him. The commercial ends with the slogan 'Just do it.' This example refers to the specific media conditions of watching moving images, in other words, the separateness of the spheres of mediated sounds and images and real life by drawing attention to the fourth wall.

Self-reference in moving image advertising is by no means a particularity of American commercials. The advertising campaign for ICA, the leading grocery retailer in Sweden, would lend itself equally well to studying the gamut of self-reference in moving image advertising. The ICA supermarket commercial series was included in the The Guinness Book of Records in 2007 for being the longest-running television advertising drama, having started in 2001. After 512

34 'Retro Michael Jordan and Spike Lee Commercial', https://www.youtube.com/watch?v=Abr_ LU822rQ (last accessed 6 April 2021).

35 'Early 9o's Bo Jackson Nike Commercial with Denis Leary', https://www.youtube.com/ watch?v=ag6kzktWR78 (last accessed 24 August 2016). 
episodes, Carl Johan 'Loa' Falkman replaced Hans Mosesson as 'Stig' in $2015{ }^{36}$ The 45-second episodes about store manager Stig and his ICA store advertise the weekly groceries on sale in different and often self-referential ways. 'ICA - Jamie Oliver ${ }^{37}$ draws attention to the production process of commercials and takes the viewer backstage to witness the rude, arrogant, and ill-tempered appearance of guest Jamie Oliver, who even gives Stig the cold shoulder. The famous British chef only puts on his winning smile when the camera is running, and with an exuberant hug, presents Stig as 'one of my oldest friends, Steve from Ikea'. The commercial stages a clash between the backstage and onstage personas of Oliver and displays self-mockery both on the part of Oliver and of the ICA corporation, which self-ironically plays with the fact that ICA is mistaken for Ikea, a Swedish brand that, unlike ICA, is internationally known.

In 'ICA Sales Problem, ${ }^{3}{ }^{8}$ ICA employees deliberate how to tell their clients that ICA products are on sale. Staff members suggest producing commercials to advertise products on sale. Each proposition - all of which are actually successfully practised by ICA - is turned down by the head of the meeting because he does not think that TV spots will work. This commercial bluntly parodies ICA's own advertising practices. But there is more to it: 'ICA Sales Problem' is a Norwegian commercial. From 2005 to 2008 , the ICA campaign model was exported to Norway, but the commercials were still made in Sweden by the same agency, King. The Swedish like to tell jokes about their Norwegian neighbours (and vice versa), and the spot makes fun of Norwegians for being ignorant about how to advertise or being too stupid to recognize that they actually do advertise.

A similar sensibility can be found in 'Reklam i verkligheten' (Commercials in Real Life): ${ }^{39}$ the commercial is set during summer vacation when presumably no one is watching TV, so the ICA employees decide to come to the viewers instead. This means that they approach people in public spaces and obtrusively put products and price tags in front of them. People seem to react 'naturally', as if filmed by a hidden camera. After a while, someone

36 See ICA 'Hans Mosesson slutar som ICA-Stig',

http://www.ica.se/erbjudanden/icas-reklamfilmer/hans-mosesson-slutar-som-ica-stig/ (last accessed 6 April 2021).

37 'Ica Reklam - Jamie Oliver (V. 50)',

https://www.youtube.com/watch?v=ZBf66 $7 \mathrm{sBCmo}$; in lower quality, but with English subtitles: https://www.youtube.com/watch?v=epGFPxJUusM (last accessed 6 April 2021).

38 'Funny ICA Ad "Salesproblem",

https://www.youtube.com/watch?v=cJx_QWaR3sw (last accessed 6 April 2021).

39 'ICA reklamfilm 2015 v.30 - Reklam i verkligheten', https://www.youtube.com/ watch? $\mathrm{v}=\mathrm{sShpgfwH} 4 \mathrm{n} 4$ (last accessed 6 April 2021). 
comments: 'You are a bit disturbing right now...' and gets the answer 'Yes! But that's the point! It's advertising!' Again, advertising practices are staged in a self-parodying way, acknowledging awareness of their often disturbing and obtrusive character. It is a feature of the ad campaign that each advertised product has a prominent price tag in big white numbers attached to it. In each episode, foods with price tags are displayed most ostentatiously and make fun of the allegedly 'inconspicuousness' of product placement. This alone refers to advertising practice in a humorous way.

Commercials that refer to their own historicity often work with split screens to contrast a historical commercial with a new one. 'Tomorrow's Classics' for Volvo S6o (2006) is mentioned in Bo Florin's chapter 'Moving Objects: The Case of Volvo' as a typical example of this strategy. In the series of commercials for the German insurance company Allianz called Allianz Klassiker (Allianz Classics; started in 2015), commercials from 35 years ago are placed on the left side of the screen: for example, the commercial 'Tomatenstapel' (Pile of Tomatoes) ${ }^{40}$ for car insurance or 'Unfall' (Accident) ${ }^{41}$ for casualty insurance. On the right-hand side of the screen, there is a shotfor-shot remake of the old commercial, but the new version is adapted to the present and features new accident risks (skateboard instead of banana peel), up-to-date communication technology (tablet or smartphone instead of written papers), and changed gender roles (the mother of the family goes out for work while the father stays home). In the final image of the commercials, the corporation's slogan 'Eine Allianz fürs Leben' (A Lifelong Alliance) is completed with 'Damals wie heute' (Then as Now). Rather than parody, moving image advertising referring to its own history is a nostalgic reminder of past advertising practices, if not of the past itself. As an advertising strategy, it promises stability and continuity, and thus a sense of security in today's complex and rapidly changing world. In these examples, self-reflective nostalgia serves as a means to build consumer confidence and loyalty. It is therefore no coincidence that an insurance company pursues this strategy.

Quite differently, commercials that draw attention to the mediality of moving image advertising play on the funny clash between the laws of reality and of mediated reality. The diegesis of the Heineken commercial 'Lip Sync Drama' (UK 1988) ${ }^{42}$ is set in a classical drama world. A yearning

40 'Allianz Klassiker: 35 Jahre später - manche Dinge ändern sich nie', https://www.youtube. com/watch?v=NZM5-1c9D5o (last accessed 6 April 2021).

41 'Allianz Klassiker: Der Film „Unfall“ 35 Jahre später', https://www.youtube.com/watch? v=ysGVT6mo1yA (last accessed 6 April 2021).

42 'Heineken - Lip Sync Drama (1988, UK)',

https://www.youtube.com/watch?v=AaBxNOUgEJQ (last accessed 25 August 2016). 
couple in a chi-chi colonial-style hotel experiences a serious problem: they are talking out of sync! But after drinking a glass of Heineken, sound and image are in sync again and the commercial, clearly a parody of Hollywood genre conventions, gets its happy ending. In a similar vein, a commercial for Aristoc tights, ${ }^{43}$ shot in widescreen in the style of a visually sophisticated art-house movie, derives its humour from a character's impossible knowledge on a technical feature of post-production: an attractive woman seeks to discuss a serious problem with her partner. Their Italian dialogue is subtitled in English. What sounded like a relationship problem turns out to be a subtitle problem: the woman complains about the positioning of her subtitles, for they are not at the bottom of the image, but on top so that they cover her face. Her partner explains that this is because she is wearing Aristoc Slimline System tights, and that it would be a crime to cover them up. When the woman takes a seat in a chair with her legs posed for the final product presentation, the Aristoc tights package fades in to cover not only her face, but the entire upper part of her body. During the whole commercial, all attention is on her legs; her face is never shown. Here again, the boundaries between the diegesis of the commercial and the commercial as a media object are transgressed, but this time to make fun of product-staging practices in advertising, which could not care less about gender neutrality or reducing women to their legs.

\section{What Do Self-Referential Advertisements Know about Advertising that We Don't Already Know?}

Many more examples could be added to describe the variegated facets of self-reference in moving image advertising. Writing about self-reference poses a somewhat similar problem as writing about intermediality: the phenomenon can be located in its many places and analysed in its many forms. But what else do we get out of that except acknowledging that the phenomenon exists in various locations and manifestations? With its claim that self-reference in advertising provides knowledge about advertising, systems theory suggests an answer to this problem that critical theory cannot. But what exactly can we learn from self-referential moving image advertisements about advertising that we don't already know? So far, it has become evident that self-referential commercials display an

43 'Aristoc funnyz',

https://www.youtube.com/watch?v=pUxCirLX4bE (last accessed 6 April 2021). 
awareness that they are advertisements. Or, as Michael Dunne puts it, '[s]elf-referential ads openly advertise that they are advertisements and assume that their audiences know this perfectly well'. ${ }^{44}$ Since audiences generally know that advertising is advertising, especially if they are plainly told so by the advertisements themselves, self-disclosing the attempt to influence is a strategy to overcome possible resistance to persuasion and to cause the viewers' attitude towards a brand to be more favourable, but it does not yet provide new knowledge about advertising. What is there, then, to learn from self-reference in moving image advertising, beyond what we already know? Some more examples will help to explore this question.

A series of television advertisements for Isuzu cars and trucks that aired on American television from 1986 to 1990 is based on reflexivity about the nature of advertisements. ${ }^{45}$ The fictional spokesman of the series is Joe Isuzu, a pathological liar who makes outrageous and overinflated claims about Isuzu cars and trucks. The commercial 'Save a Billion" ${ }^{36}$ refers to the popular advertising strategy that the more you buy, the more you could save, and extends this argument ad absurdum: Joe Isuzu directly addresses the audience and invites them to buy one thousand Isuzu troopers in order to save two million dollars, or even better, to by one million troopers and save two billion dollars. To illustrate the absurdity, the screen is split into tons of tiny little images of miniature troopers while Isuzu is shown standing amidst heaps and heaps of dollar bills. In 'Joe Isuzu for Isuzu Pup', ${ }^{47}$ Isuzu presents a man in the background as a Supreme Court justice to verify his claims. A subtitle appears to contradict this information, pointing out 'He's lying. That's his cousin.' Later in the commercial, Joe Isuzu announces that if you buy one pickup, you get one free. This message is countered by a subtitle reading 'We are generous, not stupid.' Each commercial in the series closes with the slogan 'You have my word on it.'

The commercials tell us, in a satirical way, that car salesmen and car ads are dishonest. They expose the excess and exaggeration of advertising. If I use the word 'expose', I mean it in the sense of 'exhibiting' rather than in the sense of 'revealing', because audiences have known about the excess and exaggeration of advertising for a long time. The commercials neither

44 Dunne, Metapop, viii.

45 The series was created by the ad agency Della Femina, Travisano, and Partners.

46 'Isuzu “Save a Billion”', https://www.youtube.com/watch? $\mathrm{v}=\mathrm{xFIcjfWvNYw} \mathrm{(last} \mathrm{accessed}$ 6 April 2021).

47 'Joe Isuzu for the Isuzu Pup', https://www.youtube.com/watch?v=SNOvNrZ6S_E (last accessed 6 April 2021). 

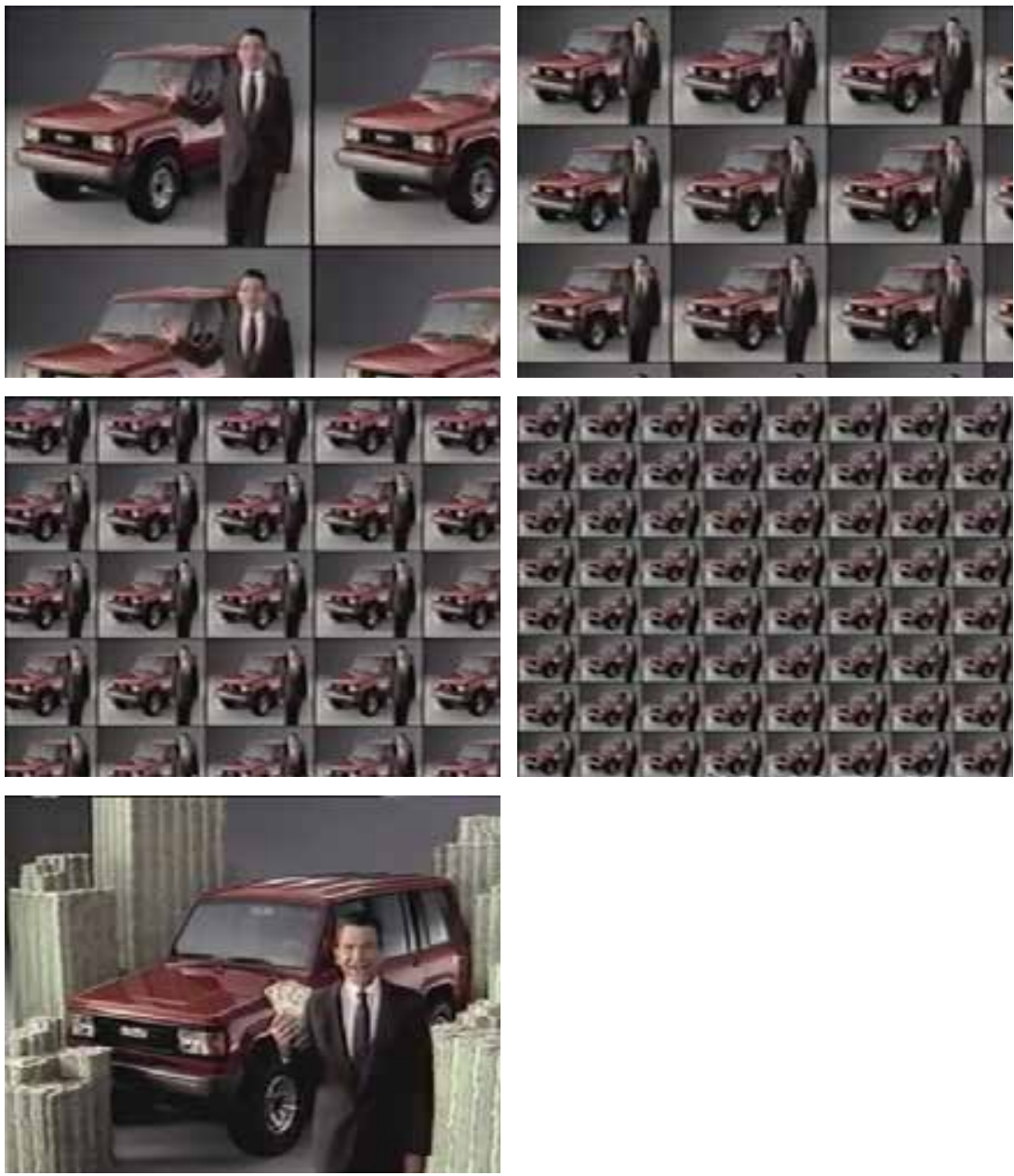

Figures 7.1-7.5: Joe Isuzu in 'Save a Billion'.

uncover a hidden fact nor conceal a hidden agenda. Instead, they ostentatiously exhibit what the audience is already well aware of. In The Reality of the Mass Media, Niklas Luhmann writes about advertising, stating that '[a] dvertising seeks to manipulate, it works insincerely and assumes that that is taken for granted'. ${ }^{48}$ With regard to self-reference, Luhmann's statement can be used to argue that self-reference in advertising makes explicit and exhibits what advertisers assume is taken for granted by the audience.

48 Niklas Luhmann, The Reality of the Mass Media, trans. by Kathleen Cross (Stanford: Stanford University Press, 200o), 44. 
The next example refers to the economy of advertising: the 20oo Super Bowl commercial 'Wasted \$2 Million Bucks ${ }^{49}$ for $\mathrm{E}^{*}$ Trade features the company's advertising character, the so-called E*Trade Monkey, together with two goony men sitting in a garage and clapping along to a version of the traditional Spanish folk song 'La Cucaracha'. The line at the end of the commercial says that the company has just wasted two million dollars on this commercial. It is commonly known that Super Bowl ads are extremely expensive, possibly the most expensive ads. According to Time, the 30-second commercials that ran during the 2011 Super Bowl cost an average of $\$ 3.5$ million each. ${ }^{5^{0}}$ So the amount mentioned in the commercial is realistic. It is also commonly known that advertisers struggle to predict the response to their advertising; in other words, to follow marketing pioneer John Wanamaker, we as consumers understand that advertisers know that half the money that they spend on advertising is wasted - they just never know which half. So, again, we have not learned anything about the economy of advertising from this example that we didn't already know. On the contrary, the commercial builds its joke on the very assumption that we know this.

Self-reference in the discussed commercials does not produce knowledge on the process of advertising, neither does it reveal nor conceal any hidden agenda of the advertisers. Instead, it acknowledges that consumers have a clear notion of the aims and workings of advertising. Self-reference in moving image advertising operates on the premise of a knowledgeable audience and demonstrates the viewers' competence and advertising literacy as well as, more generally, the viewers' literacy in media and popular culture. This media literacy is acknowledged and celebrated in many of the Energizer battery television commercials starring the marketing mascot, the Energizer Bunny. The commercial series starting in 1989 drew on popular Hollywood movies - such as King Kong, Star Wars, James Bond, and Wile E. Coyote - and restaged scenes and characters to create an environment for the Energizer Bunny to co-inhabit. In each episode, the Energizer Bunny is on the verge of being eliminated, but either the batteries run out in the (fake) competitor's weapon, or there are other obstacles that prevent the villain from capturing the Energizer Bunny; for example, a window shuts on the toes of King Kong

49 'Super Bowl Ad (99?) E*Trade - "Wasted \$2 Million Bucks"', https://www.youtube.com/ watch?v=BnQMq5wtZcg (last accessed 6 April 2021).

50 Popular television programmes such as American Idol pull in approximately $\$ 475,000$ per 30 -second spot, according to $A d W e e k$. Even less popular nationally televised programmes, says AdWeek, often charged in excess of $\$ 100,000$ for a 30 -second spot in 2011. Nancy Wagner, 'How Much Does Television Advertising Really Cost?', Chron.com [n.d.], http://smallbusiness.chron. com/much-television-advertising-really-cost-58718.html (last accessed 6 April 2021). 

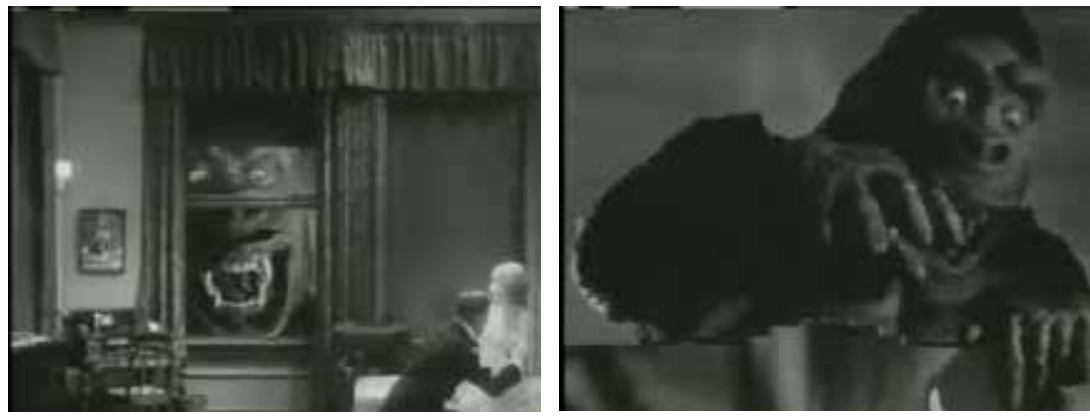

Figures 7.6-7.7: Energizer Bunny and 'King Kong'.

and makes him fall off the Empire State Building before he gets hold of the Energizer Bunny who, incessantly beating his drum, 'keeps going and going and going', as the slogan of the campaign has it..$^{1}$ These commercials are built on viewers' familiarity with popular movie culture. Another strand of Energizer Bunny commercials refers to the advertising system itself when fake commercials for headache tablets, underwear, or breakfast cereals for children serve as an environment for Energizer Bunny to invade. These commercials are based on the assumption that audiences perfectly know what 'ordinary' advertisements look like, or in other words, that viewers are familiar with the conventions of commercials.

Moreover, the Energizer Bunny's invasion of other commercials adds a self-reflective meta- or hyper-level layer that exhibits in a humorous way the fact that commercials communicate with commercials. Self-referential advertising more ostentatiously than any other kind of advertisement exhibits that advertising first and foremost is about advertising - and not about products or services. It makes explicit how commercials observe other commercials, how commercials address and respond to each other, and how they make fun of one another. Self-referential advertisements demonstrate how advertising competes with advertising. More than any other example, the series of mutually targeted television advertisements and marketing campaigns between Coca-Cola and Pepsi-Cola in the 196os known as the 'cola wars' illustrates this fact. A lesser known, but vivid case in point is the DHL commercial 'Trojan Mailing', $5^{2}$ which documents how DHL tricked its competitors into involuntarily and unknowingly advertising for

$5^{1}$ 'Energizer Bunny ${ }^{\circ}$ - King Kong - 1993 Tv Commercial', https://www.youtube.com/ watch?v=RUMvkGaI-3c (last accessed 6 April 2021).

$5^{2}$ 'Trojan Mailing', https://www.youtube.com/watch?v=vHVWegNfQlo (last accessed 6 April 2021). 
DHL. Giant packages were taped all over with thermo-active foil and cooled down below the freezing point. Competitors picked up a black package that transformed at temperatures above freezing, with the result that they delivered DHL packages. The voice-over narrator presents the ruse as 'an innovative way to communicate', much cheaper than a classical advertising campaign. The commercial closes with a sarcastic 'Thank you very much' addressed to the competitors.

Self-reference makes visible - and thus observable, to use systems theory's terms and premises - that within the advertising system, competition first and foremost is between advertisements, and not between brands, products, and services. Self-reference exposes the fact that advertising is competition in communication rather than competition in commodity. Therefore, Goldman and Papson refer to advertising as a 'sign contest' or 'sign war'. As early as 1928, advertising pioneer Edward L. Bernays predicted that commodities would increasingly be sold through advertising differentiation rather than product differentiation when he wrote: 'I believe that competition in the future will not be only an advertising competition between individual products or between big associations, but that it will in addition be a competition of propaganda'. 53

But apart from this (rather obvious) fact, which is at the heart of advertising studies indebted to systems theory, what else can be learned from the above-mentioned examples? The examined commercials illustrate that self-referential advertisements are neither a privileged source of knowledge about the processes of advertising nor a perverted tool for consumer manipulation. Rather, self-referential commercials openly advertise the assumed knowledge that viewers have about advertising and media at large. Therefore, self-reference in moving image advertising can be interpreted as an acknowledgement, exhibition, and celebration of the viewers' media competence.

\section{Self-Reference as a Mode of Address}

Speaking of the audience, it is crucial to note that different forms of selfreference in art, popular media culture, and advertising are based on different concepts of the audience. Whereas modern art, including the cinematic avant-garde, acts on the assumption of an illiterate audience that suffers from media incompetence and is therefore in need of education 
and enlightenment, moving image advertisements address the audience as media literate, competent, and knowledgeable.

The different forms of self-reference can then be seen as resulting from different ideas about the audience - and these concepts of the audience are reflected in different modes of audience address. Robert Stam distinguishes three perennial modes of reflexive art that can be helpful to illuminate this point. These three modes are ludic, aggressive, and didactic. The ludic mode, according to Stam, is illustrated by the playful self-referentiality of a Keaton two-reeler or a TV sitcom, the aggressive mode is represented by the modernist dehumanization typical of Buñuel's L'Age d'or (1930), while the didactic mode is characterized by the Brechtian materialist fictions of Godard and Alain Tanner. ${ }^{54}$ Clearly, the self-reflective works of the cinematic avant-garde in the interwar period also belong in this third category.

From the perspective of advertising, a fourth mode of reflexivity needs to be added to this list, the celebratory mode, which is predominant in self-referential moving image advertising. It is not limited to advertising, however, for it is present in popular media culture at large. This mode takes the viewers' media competence seriously and addresses the viewer as an emancipated spectator in the sense outlined by Jacques Rancière..$^{55}$ The very fact that self-referential commercials' take the audience's media expertise seriously is an important part of the fun of self-referential moving image advertisements, besides self-irony, parody, and satire. Of course, this is not exactly a new observation. Studies on self-reference in popular culture and (moving image) advertising unanimously remark that self-reference recognizes a savvy, media-literate audience. But scholars mention it only in passing and do not reflect on the importance and meaning of this fact. Or, to put it differently, they do not take the viewers' media expertise seriously enough to consider its theoretical and conceptual consequences.

If we do, it becomes evident that self-reference's referring to the text is basically a way of referring to the audience. Self-reference in this light appears less as a textual feature than a semi-pragmatic operation. Self-reference can be conceptualized as a communication strategy, or a particular mode of address that within different espaces de communication, different spaces of communication - to refer to a concept suggested by Roger Odin - elicits particular reading modes and establishes particular forms of connectivity 
between text and audience. ${ }^{5}$ Self-reference can therefore be considered a technique to shape the relationship between text and viewer. As such, it can be a used as a strategy to connect viewers to the text, but also to disconnect them from the text. In regard to moving image advertising, self-reference works as a strategy to connect text and viewer by means of celebrating shared media knowledge.

From a larger perspective of self-reference in art and media, a closer look at self-reference in moving image advertising suggests that it is more productive to understand self-reference as a mode of address that regulates the relation between viewer and text in terms of closeness and distance than to make value distinctions between critical and thus authentic forms of self-reference and assertive, celebratory, and therefore debased forms of self-reference. From this perspective, self-reference is no longer understood as a form of either concealment or revelation, but as a form of exhibition - a form that exhibits the assumed media knowledge of the viewers as much as it displays the medium itself.

\section{Self-Reference in the History of Moving Image Advertising}

Self-reference is widely considered a characteristic of postmodernity, and one could therefore anticipate an increase in self-referential commercials in history. In her study on commercial intertextuality, Gloria Withalm holds that moving image advertising has always referred to popular media culture and used movie and television stars to promote brands. In the 1970s, Withalm observes a decline in intertextuality, but in the 1980 s she sees advertisers taking up the production of self-referential advertising again, and in the 199os, the trend was evident in advertisements for all products. ${ }^{57}$ Withalm's observation is in line with Goldman and Papson's claim that the late 1980 s also saw a massive increase in moving image advertisements that made use of enunciative and metatextual self-reference. ${ }^{8}$ Unlike Withalm, who grants intertextuality in moving image advertising a history that dates back to the emergence of the movies, Goldman and Papson consider self-referential commercials to be a new phenomenon of the late 1980 s,

56 Roger Odin, Les Espaces de communication: Introduction à la sémio-pragmatique (Grenoble: Presses universitaires de Grenoble, 2011).

57 Withalm, 'Commercial Intertextuality,' 425-435.

$5^{8}$ Goldman and Papson, Sign Wars. 
when a new genre of ads emerged that 'played at being self-reflexive about the arbitrary process of meaning construction in ads'.$^{59}$

If self-reflexivity was not frequent enough through the history of moving image advertising to form a genre by itself for many decades, the argument of the 'novelty' of self-referential advertisements in the 1980s is easily disproved: 'Laveuses' (Laundresses, also known as 'Washing Day in Switzerland'), which, according to some historians, is 'the first purposive advertising film in film history, ${ }^{60}$ is also a very early example - if not the first? - of self-reference in moving image advertising. Attributed to Alexandre Promio, but shot by Emile Lavanchy in $1896,{ }^{61}$ the 'view' premiered in New York on 27 June 1896 and was subsequently screened in Lyon on 20 September $1896{ }^{62}$ This commercial for Sunlight Soap was initiated by François-Henri Lavanchy-Clarke, the licence holder of the Cinémathographe Lumière in Switzerland, who also happened to be the representative in that country of Lever Brothers, manufacturers of Sunlight soap. The reason why Lavanchy-Clarke acquired the licence of the Cinémathographe Lumière, which allowed the shooting and projection of moving images with the same device, was the possibility to promote his licensed products in an innovative new way. ${ }^{63}$ Interestingly enough, there are two different versions of this putatively first advertising film. While one version is innocent of any self-reference, ${ }^{64}$ the 'official' version, ${ }^{65}$ listed in the Catalogue Lumière as 'Vue no. 6o' ${ }^{66}$ shows Lavanchy-Clarke entering the scene from the right-hand corner of the screen and instructing a little girl to hand over a small bucket of water to an older girl who stands on a wooden box labelled 'Sunlight Savon' (Sunlight Soap) and helps two

59 Ibid., 17.

6 o Jeanpaul Goergen, 'Drei Männer und die Anfänge des deutschen Werbefilms', in Werbefilme: Spiegel der Zeiten - Chronik des Alltags, ed. Hans-Gerd Schmidt and Bernd Wiesener (Bielefeld: Verlag für Regionalgeschichte, 2002), 171.

61 See 'Francois-Henri Lavanchy-Clarke', Who's Who of Victorian Cinema, http://www.victoriancinema.net/lavanchyclarke (last accessed 6 April 2021).

62 'L'œuvre cinématographique des frères Lumière: Laveuses Vue No 6o', https://cataloguelumiere.com/laveuses/ (last accessed 6 April 2021).

63 See Roland Cosandey, 'Le Catalogue Lumière 1896-1907 et la Suisse: Éléments pour une filmographie nationale', 1895, no. 14 (December 1993); Roland Cosandey and Jean-Marie Pastor, 'Lavanchy-Clarke: Sunlight \& Lumière, ou les debuts du cinématographe en Suisse', Equinox, no. 7 (June 1992). For a similar strategy to promote consumer goods with the latest technology of moving images, see Martin Loiperdinger, Film \& Schokolade: Stollwercks Geschäfte mit lebenden Bildern (Basel: Stroemfeld, 1999).

64 https://www.youtube.com/watch?v=ztV6zDmoiCs (last accessed 30 August 2016).

65 'Auguste \& Louis Lumière: Laveuses (1896)', https://www.youtube.com/watch?v=uhoI TDfQpwU (last accessed 6 April 2021).

66 'L'œuvre cinématographique des frères Lumière: Laveuses Vue No 6o'. 


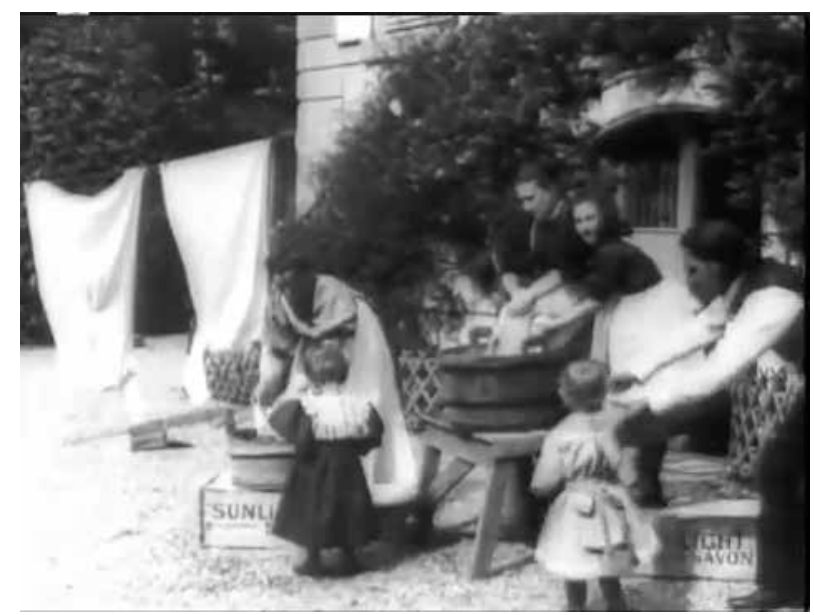

Figure 7.8: François-Henri Lavanchy-Clarke appearing in 'Laveuses'.

women washing clothes in a wooden tub. Another wooden box labelled in German - 'Sunlight Seife'- is placed on the left-hand corner of the screen. With this kind of product placement, two language communities could be reached at a single stroke. Lavanchy-Clarke's appearance in person brands the commercial with his personal figure (in the sense of Hitchcock's later cameos in his movies), a strategy that Lavanchy-Clarke used, like many (local) film pioneers, to 'sign' his moving pictures. At the same time, the appearances allowed the producers of early films, be they actualities, local views, or advertising films, to encourage people in the picture to move so that the new technological possibilities to reproduce movement could be fully exploited. Equally important, Lavanchy-Clarke's entry draws attention to the production process of the 'view' and its constructed nature. In doing so, it refers to the apparatus that makes the construction possible in the first place.

Self-reference in 'Laveuses' can be considered a typical example of what Tom Gunning has termed 'the cinema of attractions', which is characterized by an explicit gesture of presentation and exhibition by means of frontal staging, posing for the camera, directly addressing the audience, and drawing attention to the production process. Moving image advertising has shared these practices with early cinema since its joint and entangled emergence, but while feature fictions developed towards a system of representation and narrative integration, moving image advertising (together with some other cinematic forms) has continued to rely heavily on modes of representation and address that are characteristic of early cinema. 


\section{Reconsidering Media History through the Lens of Advertising}

Early cinema has been acknowledged as a highly self-reflective period. As David Thorburn and Henry Jenkins, in concert with other scholars, have pointed out, "the introduction of a new technology always seems to provoke thoughtfulness, reflection, and self-examination in the culture seeking to absorb it'. ${ }^{6}$ If periods of media change are characterized by an acute self-consciousness, it comes as no surprise that the history of self-reference in moving image advertising can be traced to the emergence of the form, that is, to the beginning of moving images. Still, Goldman and Papson's diagnosis of a substantial proliferation of commercials that refer to themselves or other commercials in the 1980 s is correct. From a larger perspective, while acknowledging the precedents in high and popular art, Dunne similarly holds that self-reference has become much more common and more elaborate in popular culture since the 1980s. Dunne reads this proliferation of self-reference in media as a symptom of an increasing immersion of the audience in all forms of mediation. ${ }^{68}$ This observation does not necessarily stand in contradiction to the assumption that self-reference is a typical feature for media transitions. But the 'problem' with postmodernity is, as Nana Verhoeff has explained, that with its advent, recognizing selfreflexivity has become 'a bit of a platitude', and that it needs to be specified 'what it is that self-reflection puts on the table. When referencing each other, pointing out their own mediated status, media texts suggest very different agendas, different degrees and directions, even destinations, of self-reflexivity' ${ }^{69}$ While I could not agree more with Verhoeff's call for a differentiated examination of self-reference in various fields of media, I would add that a similar approach to self-reference is necessary also in regard to modernism. Feuer's admonition that Hollywood musical needs to be properly situated in the history of entertainment to understand this particular type of self-reference (and to not mistake it as modernist

67 David Thorburn and Henry Jenkins, 'Toward an Aesthetics of Transition', in Rethinking Media Change: The Aesthetics of Transition, ed. David Thorburn and Henry Jenkins (Cambridge, MA: MIT Press, 2003), 4.

68 Dunne, Metapop, 11. On increasing reflexivity from a larger social perspective, largely interpreted as a result of economic deregulation and the transition from organized to 'disorganized' capitalism (Lash and Urry) in the 1980s. See, for example, Anthony Giddens, Modernity and Self-Identity (Cambridge: Polity, 1991); Ulrich Beck, Risk Society: Towards a New Modernity, trans. Mark Ritter (London: Sage, 1992); Scott Lash and John Urry, Economies of Signs and Space (London: Sage, 1994).

69 Nana Verhoeff, Mobile Screens: The Visual Regime of Navigation (Amsterdam: Amsterdam University Press, 2012), 54. 
self-reference $)^{70}$ is equally relevant for research into self-reference into moving image advertising.

The history of self-reference in moving image advertising before postmodernism is still to be written. To frame such an endeavour methodologically and conceptually, self-reference could be understood as a symptom of media transition, as suggested by Thorburn and Jenkins and others, and at the same time, it could be examined as a sign of increasing mediation, as suggested by Dunne. If self-reference is understood as a mode of address rather than a textual feature, as I suggest in this essay, self-reference could also be studied as an indicator of assumed media expertise of the viewers. In this way, selfreferential media, be it moving image advertising, art, literature, or cinema could be questioned for what media assume their audiences know - or do not know and are therefore in need of education - about respective media. Such an approach offers a methodology that shifts the emphasis from the filmic text to reception and the viewers' media knowledge. Addressing self-reference as a source of knowledge about the assumed media knowledge of the viewers allows for the reconstruction of what kind, range, and depth of media expertise media producers do - or do not - grant their viewers. It is understood that self-reference cannot provide direct access to media expertise of historical viewers, but it can help to further open up the window to media consumption, experience, and expertise in media history, and it lends itself to a media archaeological study of the allegedly ever-increasing immersion of audiences in mediation.

'Im Filmatelier' (In the Film Studio), a puppet animation produced by German advertising film pioneer Julius Pinschewer in 1927, shows how a commercial for the painkiller Aspirin is shot. ${ }^{11}$ While an actress, distorted with pain, is lying on a chaise longue, the director instructs her from behind the scenes on how to present the product so that the camera - and the audience - gets the best view of it. The commercial also gives instructions on the correct use of the product, so that, as the director underlines, the audience can learn from the actress. Clearly, audiences are assumed to be familiar with the practices of product display and directions for product use in commercials. The commercial for Aristoc tights discussed earlier can be interpreted as a somewhat similar, if more sophisticated, version of a moving image advertising addressing the viewers' knowledge about the conventions of product display in moving image advertising.

70 Feuer, The Hollywood Musical, 47.

71 The film is featured on the DVD Julius Pinschewer. Klassiker des Werbefilms, ed. Martin Loiperdinger (Berlin: absolut medien, 2010). 
On a different level, the 1959 animated television commercial for Instant Butter-Nut Coffee, 'Subliminal', parodies the fear of being easy prey to subliminal advertising messages..$^{2}$ Anxieties about subliminal methods of influence were addressed Vance Packard in his book The Hidden Persuaders (1957), a study of psychological techniques including subliminal tactics used by advertisers to manipulate consumer behaviour. Marketing researcher James Vicary fuelled those anxieties even further with experiments in subliminal messaging to 'eat popcorn' and 'drink Coca-Cola' at a cinema in the summer of 1957. Even though Vicary admitted five years later that the results were exaggerated, the case has remained, as Charles R. Acland in his detailed reconstruction of the event retains, 'a touchstone for awareness of subliminal advertising'.73 The cartoon makes fun of the so-called subliminal messaging when a character on a stage addresses the audience directly and announces that this commercial is going to use -it takes three attempts to pronounce the word correctly - 'subliminal' advertising, explaining that this means 'you'll never see or hear the name of the product. It will be on the screen all right but the naked eye cannot detect it'. Of course, both the name of the product and its qualities are exhibited in most obtrusive ways with bold characters and most visible flashes (which stand for the invisible flashes of the subliminal) whenever the character starts to tell a - presumably funny - story. Even the punchline of the story is drowned in images and jingling sounds that are anything but subliminal. This spoof of subliminal advertising comments on the discourses on subliminal advertising and can be interpreted as evidence of trust in consumers' serenity towards overly exaggerated claims of advertising (and media) influence.

Attention to self-reference in moving image advertising may even challenge media theoretical models of critical self-reference. The celebratory mode of audience address that the marketing-driven practice of advertising has used as action against reactance lends itself as a tool to reconsider self-reference in modernist art and media. For the ludic, aggressive, and especially the didactic mode of audience address could be questioned in light of advertising's celebratory mode of audience expertise. The disclosure of media conventions in a Godard film, for example, could just as well be interpreted as a somewhat snobbish acknowledgement of advanced media expertise on the part of a knowing audience. From this perspective, what has

72 The film is featured on the DVD Classic Food Commercials of the 5o's and 6o's, ed. Historical Archive 'Preserving History Digitally' (2009).

73 Charles R. Acland, Swift Viewing: The Popular Life of Subliminal Influence (Durham, NC and London: Duke University Press, 2012), 92. 
largely been acknowledged as film pedagogy can just as well be interpreted as a celebration of elitist media expertise. If one follows this thesis, it would be interesting to search film history for moments of transition from didactic to celebratory modes of address in certain fields, while of course keeping in mind that modes of address are neither exclusive nor successive, but possibly simultaneous and dependent on different ranges of media knowledge and experience of viewers. What one viewer may perceive as a didactic mode of address, another viewer may experience as a celebratory mode of address. After all, moving image advertising, one could conclude on a somewhat cynical note, is perhaps the only place in the history of film and cinema where media expertise of the audience has been acknowledged from the beginning and celebrated as significant knowledge ever since.

\section{Bibliography}

Acland, Charles R. Swift Viewing: The Popular Life of Subliminal Influence. Durham, NC: Duke University Press, 2011.

Allen, Jeanne. 'Self-Reflexivity in Documentary.' Ciné-Tracts 1, no. 2 (1977): 37-43. Andacht, Fernando. 'On the Use of Self-disclosure as a Mode of Audiovisual Reflexivity.' In Self-Reference in the Media, edited by Winfried Nöth and Nina Bishara, 165-182. Berlin and New York: De Gruyter, 2008.

Bartlett, Steven J., and Peter Suber, eds. Self-Reference: Reflections on Reflexivity. Dordrecht: Nijhoff, 1987.

Beck, Ulrich. Risk Society: Towards a New Modernity, translated by Mark Ritter. London: Sage, 1992.

Bernays, Edward L. Propaganda. Brooklyn: Ig publishing, 2005 [1928].

Brehm, Jack W. A Theory of Psychological Reactance. New York: Academic Press, 1966. Cosandey, Roland. 'Le Catalogue Lumière 1896-1907 et la Suisse: Éléments pour une filmographie nationale.' 1895, no. 14 (December 1993): 3-30.

Cosandey, Roland, and Jean-Marie Pastor. 'Lavanchy-Clarke: Sunlight \& Lumière, ou les debuts du cinématographe en Suisse.' Equinox, no. 7 (June 1992): 9-27.

Dunne, Michael. Metapop: Self-referentiality in Contemporary American Popular Culture. Jackson and London: University Press of Mississippi, 2010 [1992].

Feuer, Jane. The Hollywood Musical. Bloomington and Indianapolis: Indiana University Press, 1993 [1982].

'Francois-Henri Lavanchy-Clarke.' Who's Who of Victorian Cinema, http://www. victorian-cinema.net/lavanchyclarke. Last accessed 6 April 2021.

Genette, Gérard. Palimpsets. Literature in the Second Degree. Lincoln: University of Nebraska Press 1997 [1982]. 
Giddens, Anthony. Modernity and Self-Identity. Cambridge: Polity, 1991.

Goergen, Jeanpaul. 'Drei Männer und die Anfänge des deutschen Werbefilms.' In Werbefilme:Spiegel der Zeiten - Chronik des Alltags, edited by Hans-Gerd Schmidt and Bernd Wiesener, 171-195. Bielefeld: Verlag für Regionalgeschichte, 2002.

Goldman, Robert, and Stephen Papson. Sign Wars: The Cluttered Landscape of Advertising. New York and London: The Guilford Press, 1996.

Kael, Pauline. 'Spoofing and Schtik.' Atlantic Monthly (December 1965): 84-85.

Lash, Scott, and John Urry. Economies of Signs and Space. London: Sage, 1994.

'L'œuvre cinématographique des frères Lumière: Laveuses Vue No 6o.' https:// catalogue-lumiere.com/laveuses/. Last accessed 6 April 2021.

Loiperdinger, Martin. Film \& Schokolade: Stollwercks Geschäfte mit lebenden Bildern. Basel: Stroemfeld, 1999 .

Luhmann, Niklas. The Reality of the Mass Media, translated by Kathleen Cross. Stanford: Stanford University Press, 2000.

Metz, Christian. Impersonal Enunciation, or the Place of Film, translated by Cormac Deane. New York: Columbia University Press, 2016 [1991].

Metz, Christian. L'Enonciation impersonnelle, ou le site du film. Paris: Klinksieck, 1991.

Nöth, Winfried, Nina Bishara, and Britta Neitzel. 'Selbstreferenz in der Werbung.' In Mediale Selbstreferenz: Grundlagen und Fallstudien zu Werbung, Computerspiel und den Comics, 57-118. Cologne: Halem, 2008.

Nöth, Winfried, and Nina Bishara, eds. Self-Reference in the Media. Berlin and New York: De Gruyter, 2008.

Odin, Roger. Les Espaces de communication: Introduction à la sémio-pragmatique. Grenoble: Presses universitaires de Grenoble, 2011.

Rancière, Jacques. The Emancipated Spectator, translated by Gregory Elliott. New York: Verso, 2009.

Ruby, Jay. 'The Image Mirrored: Reflexivity and the Documentary Film.' In New Challenges for Documentary, edited by Alan Rosenthal, 64-77. Berkeley: University of California Press, 1988.

Schmidt, Siegfried J. 'Modes of Self-Reference in Advertsing.' In Self-Reference in the Media, edited by Winfried Nöth and Nina Bishara, 47-6o. Berlin and New York: De Gruyter, 2008.

Stam, Robert. Reflexivity in Film and Literature. From Don Quixote to Jean-Luc Godard. New York: Columbia University Press, 1992 [1985].

Thorburn, David, and Henry Jenkins, eds. Rethinking Media Change: The Aesthetics of Transition. Cambridge, MA: MIT Press, 2003.

Verhoeff, Nana. Mobile Screens: The Visual Regime of Navigation. Amsterdam: Amsterdam University Press, 2012.

von Keitz, Ursula. 'Adaption und Funktionalisierung von Spielfilmcodes im neueren Werbefilm.' Spiel 11, no. 1 (1992): 165-189. 
Wagner, Nancy. 'How Much Does Television Advertising Really Cost?' chron.com [n.d.], http://smallbusiness.chron.com/much-television-advertising-reallycost-58718.html. Last accessed 6 April 2021.

Withalm, Gloria. 'Commercial Intertextuality.' In Logica, dialogica, ideologica. I segni tra funzionalità ed eccedenza, edited by Patrizia Calefato, 425-435. Milan: Mimesis, 2003.

Withalm, Gloria. 'Commercialzation of Filmic Self-referentiality.' Semiotica 148, no. 1-4 (2004): 337-360.

Withalm, Gloria. 'Recycling Dorothy, Dinosaurs, and Dead Actors: Digi-Textuality in the TV-Commercials of the 1990s.' Semiotische Berichte 27, no. 1 (2003): 297-315. Zurstiege, Guido. Zwischen Kritik und Faszination: Was wir beobachten, wenn wir die Werbung beobachten, wie sie die Gesellschaft beobachtet. Cologne: Halem, 2005. 